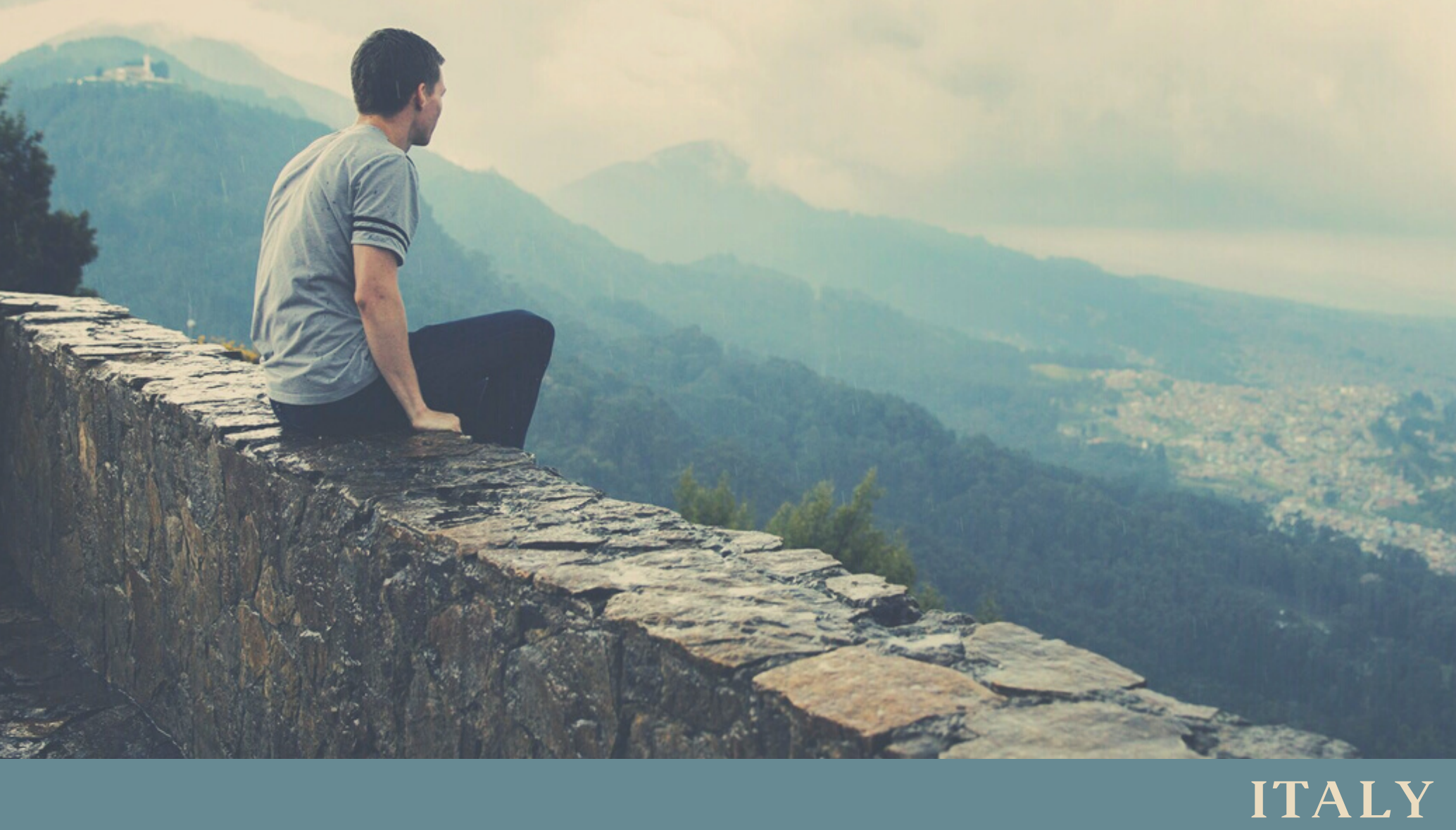

\title{
THE CASE OF ITALY
}

\section{Andrea ZATTI}

Part of Accountability, anti-corruption, and transparency policies in Public-Owned Enterprises by Andrea ZATTI (ed.), 2020-2021 
CIRIEC (International Centre of Research and Information on the Public, Social and Cooperative Economy) is a non-governmental international scientific organization.

Its objectives are to undertake and promote the collection of information, scientific research, and the publication of works on economic sectors and activities oriented towards the service of the general and collective interest: action by the State and the local and regional public authorities in economic fields (economic policy, regulation); public utilities; public and mixed enterprises at the national, regional and local levels; the so-called "social economy" (not-for-profit economy, cooperatives, mutuals, and non-profit organizations); etc.

In these fields CIRIEC seeks to offer information and opportunities for mutual enrichment to practitioners and academics and to promote international reflection and action.

CIRIEC activities, publications and researches are realized with the support of the University of Liège, the Walloon-Brussels Federation, the Walloon Region and the Belgian National Lottery.

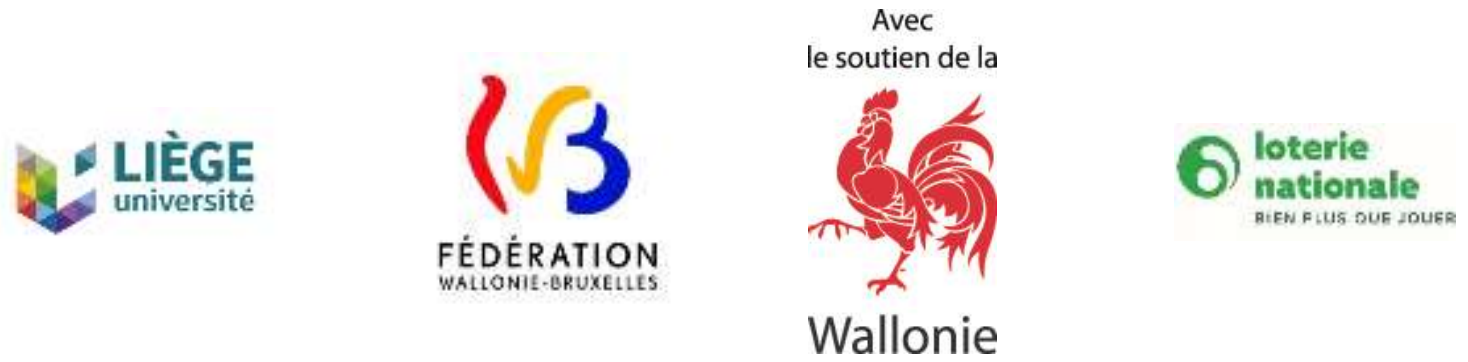

This publication has been peer-reviewed.

No part of this book may be reproduced in any form, by print, photocopy, microfilm or any other means, without prior written permission from the publisher. All rights reserved.

(C) CIRIEC aisbl, 2021

Université de Liège

Quartier Agora

Place des Orateurs, 1

Bât. B33, bte 6, BE-4000 Liège

ciriec@uliege.be; https://www.ciriec.uliege.be

ZATTI, Andrea. "The case of Italy". In: ZATTI, Andrea (ed.). Accountability, anti-corruption, and transparency policies in Public-Owned Enterprises (POEs) - Part I, Liège: CIRIEC, 2020-2021. (CIRIEC Studies Series; 2), pp. 43-60. https://doi.org/10.25518/ciriec.css2italy

This publication is indexed and available in RePEc 


\title{
The case of Italy
}

\author{
Andrea ZATTI*
}

\begin{abstract}
The third Chapter depicts the interconnections between the two themes (bribery and anti-corruption policies, on the one hand, and the role of public controlled entities, on the other) in the Italian case. Italy turns out to be an interesting case study because, on the one hand, it is among the worst performing countries in the G7 and the EU members in terms of corruption and, on the other, it has experienced a strongly proliferation of Public Owned Enterprises (POEs) during the last two or three decades, involving nearly all activity sectors of the economy. This process is deemed to have weakened the chain of control on shared units, delegating relevant financial and political decisions to a milieu of ambiguity and uncertain accountability (the 'escape' argument). A progressive change of direction occurred more recently, when corporatized public enterprises have been submitted to specific and increasing limits, including transparency and anti-corruption policies. The anticorruption package, adopted in Italy starting with 2012, has promoted important steps in this direction, yet the effects of these new measures have not been resolutive, and many challenges are still open.
\end{abstract}

Keywords: Italian case study, Corruption Perceptions Index, Anti-corruption package, Consolidated Code of Publicly Owned Enterprises, Compliance regime

JEL-Codes: D23, D73, G38, H11, K23, K42, L32

\footnotetext{
${ }^{*}$ Researcher and Professor, University of Pavia; President of the Romagnosi Foundation - Local Government School, and Rector of the Cairoli College, Pavia (Italy) (andrea.zatti@unipv.it).
} 
Analysing in the Italian case study the interconnections between the two themes considered in this study - bribery and anticorruption policies, on the one hand, and the proliferation of public controlled entities, on the other - turns out to be interesting for at least two kinds of reasons.

Firstly, according to the 2020 Corruption Perception Index (CPI) by Transparency International ${ }^{1}$, Italy ranked 52 th on a total of 180 countries scored. As to the $\mathrm{CPI}$, on a scale from 0 to 100 , whereby 100 refers to the lack of corruption, Italy got a score of 53, with an improvement over the past few years (Figure 1), placing Italy rather among the worst performing countries in the G7 (7 out of 7) and the EU members (23 out of 27). Similarly, the Control of Corruption Index $(\mathrm{CCl})^{2}$, constructed by the World Bank as one of the six composite World Governance Indicators, is estimated to be for Italy at a value of 0,24 (2018 data), even in this case experiencing an upward trend since 2015, but still at the bottom of the EU ranking (22 out of 27). Notwithstanding, in recent years, Italy has embarked in a wide range of structural reforms, including an anticorruption package in 2012, corruption is still perceived as a key and pervasive phenomenon, affecting all sectors of society, both in the public and the private sphere (GRECO, 2017). Consequently, public trust in politicians and citizens' confidence in public service remain low (ibidem). The latest Eurobarometer on corruption, dating $2019^{3}$, reports that $91 \%$ of the Italian businesses think corruption is widespread (very widespread + fairly widespread): third highest value in the EU, where the overall average is well below (63\%).

\footnotetext{
${ }^{1}$ https://www.transparency.org/en/cpi/2020/index/ita . The CPI is calculated using 13 different data sources from 12 different institutions that capture perceptions of corruption within the previous two years.

${ }^{2} \mathrm{CCl}$ is estimated on a scale of -2.5 to +2.5 , where the higher the index the less the corruption indicated. $\mathrm{CCl}$ reflects perceptions of the extent to which public power is exercised for private gain, including both petty and grand forms of corruption, as well as "capture" of the state by elites and private interests. https://databank.worldbank.org/databases/control-of-corruption .

${ }^{3}$ Flash Eurobarometer 482.
} 
Figure 1. Corruption Perceptions Index-CPI: the rank of Italy

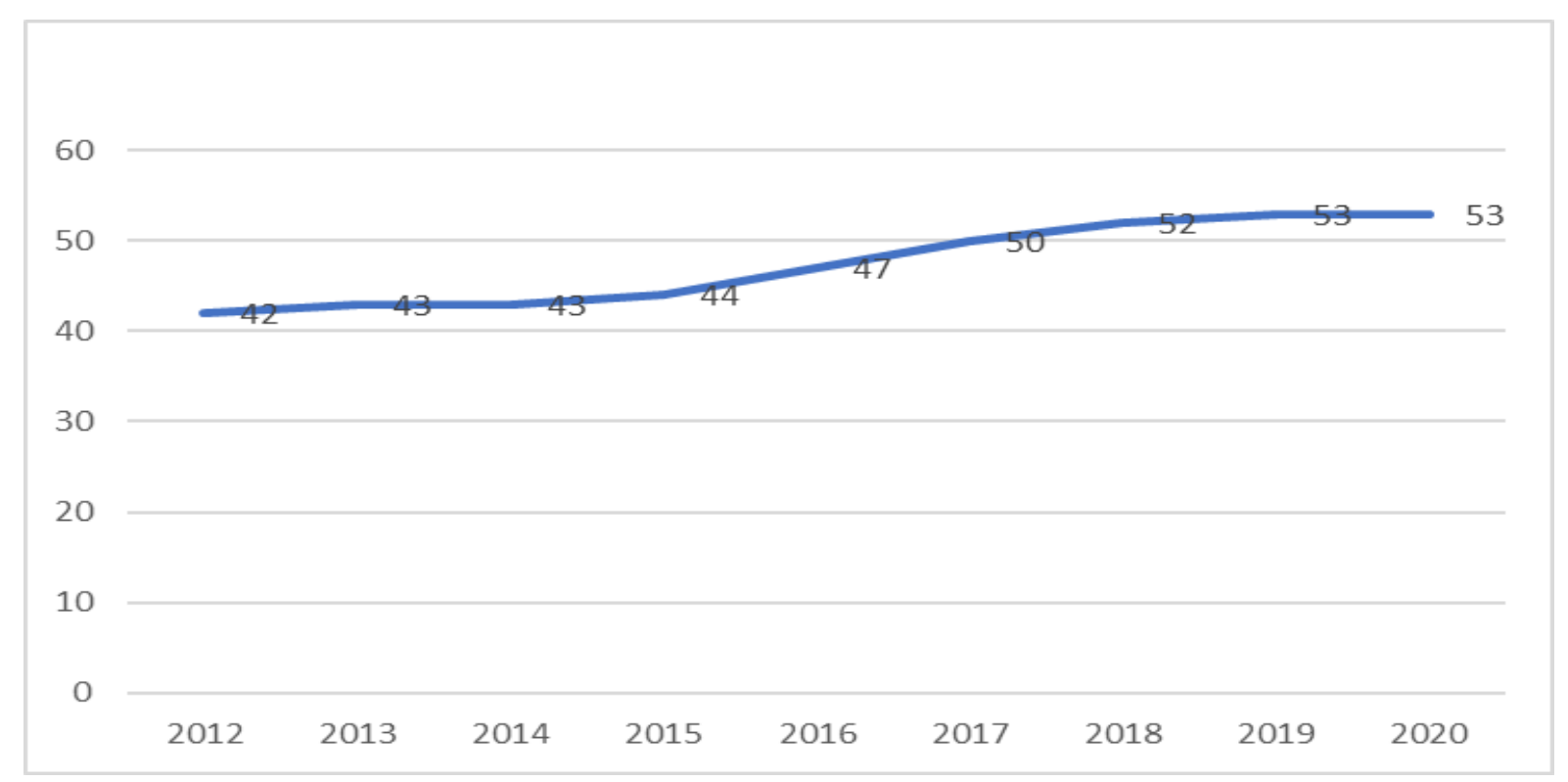

Source: Elaborations on Transparency international, several years.

Secondly, POEs, above all local POEs, strongly flourished in Italy during the last two or three decades, involving nearly all activity sectors of the economy (Zatti, 2013; Karantounias \& Pinelli, 2016; Bertocchi, 2017; Corte dei Conti, 2019; MEF, 2019a; Belhoncine \& Jirasavetakul, 2020; Istat, 2020). This phenomenon, mainly characterized by the creation of private-law corporate structures, has been initially driven by a mounting economic, political, ideological and theoretical background, aimed to shape the public sector in a more business-like fashion by introducing principles and tools of private management into public administration in order to improve POEs' performance (McDonald, 2016; Previtali et al., 2018). More recently, POEs have also become an instrument of re-publicization in the provision of services of general interest previously outsourced: an evolution fostered, among others, by the economic crisis and by the reappraisal of the merits of the public approach (European Commission, 2016; McDonald, 2016; Wollmann, 2018). As a whole, de-integration and reduced political control have been often the cause of unintended critical effects, mainly due to the creation of entities that behave like private companies without the political and financial risks associated with direct private sector participation (Alexius \& Cisneros Ornberg, 2015; Previtali et al., 2018). The result has been "a multiform state participation in the economy with no clear orientation" (Karantounias \& Pinelli, 2016, p. 1) or, in the words of the Italian Court of Auditors, "an emblematic case of public intervention in the economy that has progressively acquired worrisome dimensions, demanding radical measures to limit negative effects on public finances and on the economic system in general. ${ }^{4 \prime \prime}$ (Corte dei Conti, 2018, p. 17).

\footnotetext{
${ }^{4}$ Translation by the author.
} 


\section{POEs in Italy: a general overview}

The rate of birth of new POEs has been characterized in the last decades by a reverse U-shaped curve (Figure 2), with an increasing trend till the first years of the 20th century and a clear decline in the more recent period. As a result, a plethora of publicly- and semi-publicly-owned undertakings emerged, particularly at the regional and municipal level, active in several areas: services instrumental to the public administration, administrative functions, management of state assets, network industries or other services of general interest, but even provision of services on the open market ${ }^{5}$ (Karantounias \& Pinelli, 2016; Curci et al., 2017; Corte dei Conti, 2019; Mocetti \& Roma, 2020).

Figure 2. POEs in Italy: private law companies by year of foundation

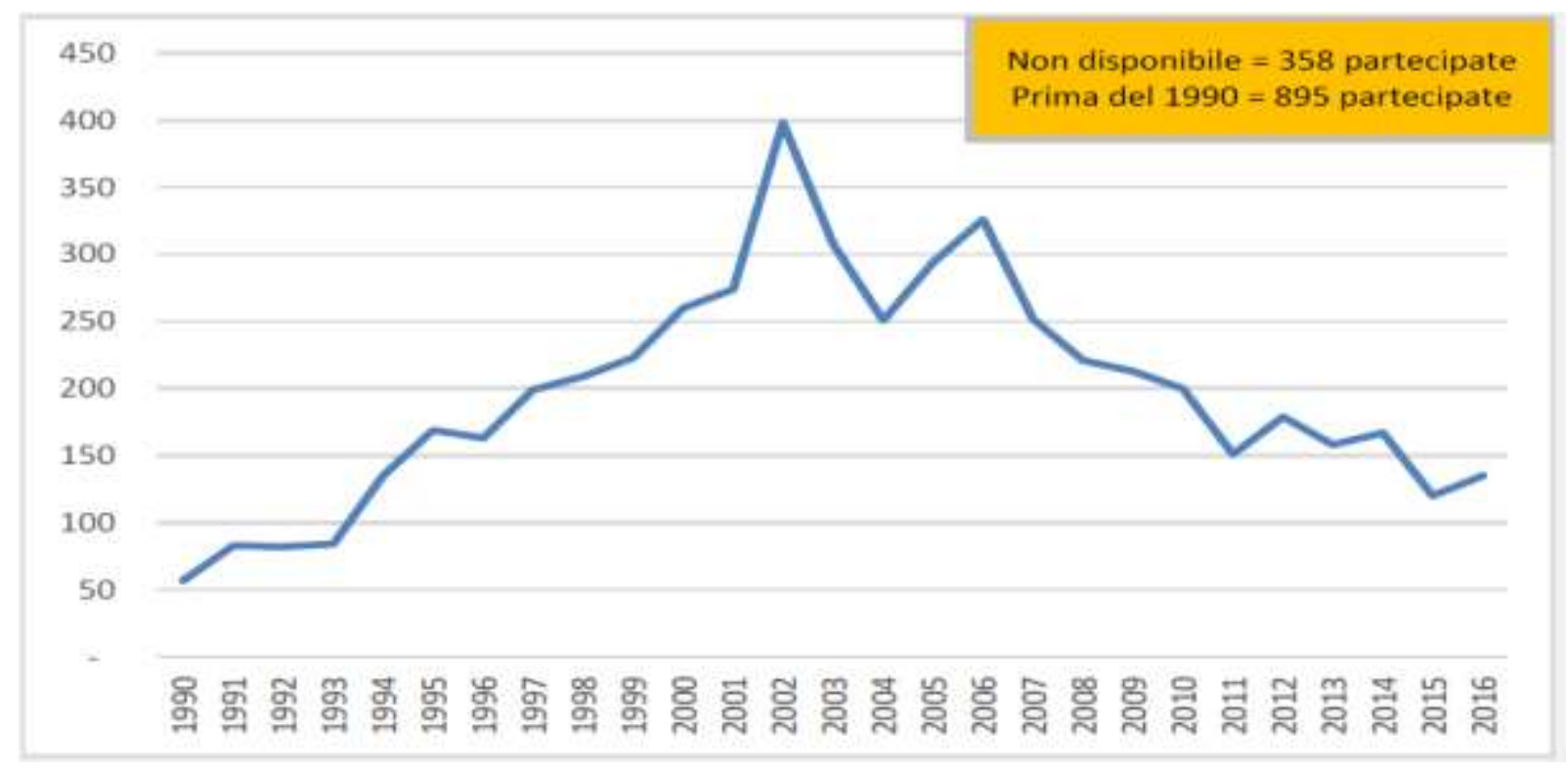

Source: Ministry of the Economy and Finance ${ }^{6}$.

POEs are numerous and difficult to monitor, even due to the presence of complex and intricate ownership relationships. The most recent investigation of the Italian Institute of Statistics ${ }^{7}$ (Istat, 2020) reports 9.118 entities participated in Italy by the public sectors in 2017 (Table 1). 6.310 are enterprises in activity, representing 70\% of total units and $96 \%$ of total people employed; 964 are non-active enterprises, and 1.844 other entities (associations, foundations, NGOs, public institutions, not classified entities), mainly operating in the agriculture sector and in non-commercial activities. Active POEs declined by $18 \%$ in the period $2012-2017$ due to the most

\footnotetext{
${ }^{5}$ Such as shops, drugstores, tourist activities, etc.

${ }^{6}$ MEF (2019a). The figure is based on a sample of 6.500 private law entities in activity in 2016 , divided by year of foundation. 850 participated companies already existed before 1990. The sample includes POEs at the national, regional and local level, both controlled and even simply participated.

${ }^{7}$ ISTAT database includes entities directly controlled and participated by public administrations and entities indirectly participated by other entities controlled by public authorities.
} 
recent reforms adopted by the Italian government that lowered the favour towards the use of private-status entities to manage the public mission (Mocetti \& Roma, 2020). This effect is less significative on people employed where the reduction, for the same period, has been of nearly $11 \%$. If we concentrate on the last two years (2015-2017) for which statistics are available, the decrease in terms of the number of active POEs $(-8 \%)$ has not been associated with any effect on the workforce ${ }^{8}$, giving evidence of a process mainly based on the elimination/aggregation of marginal units.

Table 1. Entities participated by the public sectors in Italy (2017)

\begin{tabular}{|l|c|c|c|}
\hline & N. & Under public control (\%) & People employed \\
\hline Total participated entities & 9.118 & $53,3 \%$ & 884.757 \\
\hline Active POEs & 6.310 & $59,2 \%$ & 847.232 \\
\hline Non Active POEs (in liquidation) & 964 & & $/$ \\
\hline Other entities & 1.844 & & 37.524 \\
\hline
\end{tabular}

Source: elaborations on Istat (2020).

Nearly $60 \%$ of active POEs are controlled by public entities and their share regarding total employed people is close to $75 \%$ (Table 2). At the same time there is a nonnegligible number of participated entities for whom the stake of the public shareholders appears too low for the purpose of influencing their management towards the public interest ( $26 \%$ of enterprises feature below $20 \%$ ).

Table 2. Active POEs and employment by \% of public share (2017)

\begin{tabular}{|l|r|r|r|r|}
\hline \multirow{2}{*}{} & \multicolumn{2}{|c|}{ Total } & \multicolumn{2}{c|}{ Employed people } \\
\cline { 2 - 5 } & $\mathrm{N}$. & $\%$ & $\mathrm{~N}$. & \multicolumn{1}{c|}{} \\
\hline$<20 \%$ of public share & 1.622 & 25,7 & 178.012 & 4,0 \\
\hline $20 \%<$ Public share $<=50 \%$ & 952 & 15,1 & 37.236 & 74,6 \\
\hline Public share $>50 \%$ & 3.736 & 59,2 & 631.984 & $\mathbf{1 0 0 , 0}$ \\
\hline TOTAL & $\mathbf{6 . 3 1 0}$ & $\mathbf{1 0 0 , 0}$ & $\mathbf{8 4 7 . 2 3 2}$ & \\
\hline
\end{tabular}

Source: elaborations on Istat (2020).

Private law entities represent by far the largest part (Table 3) with a share of more than $98 \%$ on both the total number of POEs and employed people ${ }^{9}$. Joint stock companies, in particular, are characterized by higher average dimensions, counting for only $1 / 3$ of total POEs, but employing nearly $83 \%$ of the whole workforce. As observed in previous surveys (Grossi \& Reichard, 2008), the process of agencification has been in Italy mainly a process of corporatization, with a dominant role of limited liabilities companies and joint stock option companies, often originated from the transformation of public legal form entities (so called aziende speciali).

\footnotetext{
${ }^{8}$ Employed people in POEs are 847.232 in 2017 against 848.705 in 2015.

${ }^{9}$ The share of private law enterprises on total active entities participated by the public sector is respectively $75,8 \%$ (total number) and $94,4 \%$ of employed people.

This result is coherent also with the outcome of the survey on entities participated by public authorities conducted by the Ministry of Economy and Finance, according to the data provided by the extraordinary review carried out in 2017. Total scrutinized entities have been 9.184 (106 data), with $81 \%$ of them having the status of private law companies or consortia (MEF, 2019a).
} 
Table 3. Active POEs: Number of entities and employment by legal form (2017)

\begin{tabular}{|c|c|c|c|}
\hline & N. entities & Employed people & Average employed people \\
\hline Joint stock companies & 1.939 & 704.589 & 363 \\
\hline Limited liability companies & 2.726 & 78.130 & 29 \\
\hline Cooperative companies & 396 & 29.047 & 73 \\
\hline Private law consortium & 1.122 & 23.153 & 21 \\
\hline Public law entities & 127 & 12.313 & 97 \\
\hline TOTAL & 6.310 & 847.232 & 134 \\
\hline
\end{tabular}

Source: elaborations on Istat (2020).

In terms of the ownership composition, local POEs ${ }^{10}$ are predominant $(4.253$, i.e $67 \%$ of total active POEs) even if their weight respect to total employed people by POEs is sharply lower (32,6\%). Considering only entities controlled by public authorities (Table 4), the leading role of the Ministry of Economics and Finance clearly arises, mainly due to the large average size of the shared entities (1.109 employed people). POEs controlled by municipal and provincial governments are very numerous ( $43 \%$ of the total number) but with a restrained weight on employment (21\%).

Table 4. POEs controlled by public authorities (total number and \%) (2017)

\begin{tabular}{|l|c|c|c|c|c|}
\hline authority & $\begin{array}{c}\text { N. } \\
\text { Enterprises }\end{array}$ & $\%$ & $\begin{array}{c}\text { N. Employed } \\
\text { people }\end{array}$ & $\%$ & $\begin{array}{c}\text { Average } \\
\text { employed } \\
\text { people }\end{array}$ \\
\hline $\begin{array}{l}\text { Ministry of Economics and } \\
\text { Finance }\end{array}$ & 322 & 8,6 & 357.227 & 56,5 & 1.109 \\
\hline $\begin{array}{l}\text { Other Ministries and Central } \\
\text { Authorities }\end{array}$ & 64 & 1,7 & 1.378 & 0,2 & 22 \\
\hline Regions & 239 & 6,4 & 35.139 & 5,6 & 147 \\
\hline $\begin{array}{l}\text { Provinces, Metropolitan Cities } \\
\text { and Municipalities }\end{array}$ & 1.612 & 43,1 & 131.176 & 20,8 & 81 \\
\hline Autonomous Provinces & 46 & 1,2 & 2.137 & 0,3 & 46 \\
\hline Chamber of Commerce & 55 & 1,5 & 1.772 & 0,3 & 32 \\
\hline Healthcare system entities & 29 & 0,8 & 7.062 & 1,1 & 244 \\
\hline Other local administrations & 129 & $\mathbf{3 , 5}$ & 5.441 & 0,9 & 42 \\
\hline Singly owned entities & $\mathbf{2 . 4 9 6}$ & $\mathbf{6 6 , 8}$ & $\mathbf{5 4 1 . 3 3 1}$ & $\mathbf{8 5 , 7}$ & $\mathbf{2 1 7}$ \\
\hline Jointly owned entities & $\mathbf{1 . 2 4 0}$ & $\mathbf{3 3 , 2}$ & $\mathbf{9 0 . 6 5 3}$ & $\mathbf{1 4 , 3}$ & $\mathbf{7 3}$ \\
\hline Total & $\mathbf{3 . 7 3 6}$ & $\mathbf{1 0 0 , 0}$ & $\mathbf{6 3 1 . 9 8 4}$ & $\mathbf{1 0 0 , 0}$ & $\mathbf{1 6 9}$ \\
\hline
\end{tabular}

Source: elaborations on Istat (2020).

The shareholdings spanned over all the sectors, with a numerical prevalence of services, including professional services, technical and scientific services, and instrumental services for the public administration. In terms of employed people, the main share is represented by network industries with transport $(32,7 \%)$, and water/ sewerage/waste $(28,6 \%)$ at the top (ISTAT, 2020) ${ }^{11}$.

\footnotetext{
${ }^{10}$ POEs participated by at least one regional or local government.

${ }^{11}$ A similar figure is reported by the Court of Auditors in its yearly survey (only) on entities participated by local public authorities (Corte dei Conti, 2019). 40,75\% of them (representing $71 \%$ of the total production) are in fact enterprises providing local public services (waste, water, transport, energy, health and social services), while $59,25 \%$ provide other services, including services instrumental to the controlling authority.
} 
Beyond the ownership relationship, the use of other steering levers turns out to be uncertain, with only $37 \%$ of entities explicitly entrusted to provide goods or services for the public administration, both in terms of services of general interests and instrumental services (MEF, 2019a) ${ }^{12}$. Inside services entrusted to POEs, a strong prevalence of direct awards (94\% of contracts) is documented, while tenders (both open tenders and double tendering to mixed enterprises) assume a residual role (6\%) $\left(M E F, 2019 a ;\right.$ Corte dei Conti, 2019) ${ }^{13}$. Transfers from the public administration occur on various grounds, where compensations for public service obligations represent on average less than $50 \%$, being generally complemented by other grants and capital increases to cover losses, without a clear distinction between them (Karantounias \& Pinelli, 2016). The overall figure remains opaque, lacking a clear evidence about the prevalent nature of the participated entities (in-house or market oriented) and making it difficult to assess whether funds obtained by controlling authorities are commensurate to the benefits performed by the corresponding activity.

Even if POEs are often seen has a source of financial losses, on aggregate level a limited fiscal risk comes to light. Within the 4.326 local public entities with a financial report available for 2017, the Court of Auditors reports profits for 4,8 billion euros and losses for 1,1 billion euros (Corte dei Conti, 2019). Similarly, the Ministry of Economics and Finance (MEF, 2019b) reports that $62,5 \%$ of corporations participated by local governments has experienced profits in 2016, with better results for entities with a higher public share. Mocetti \& Roma (2020), focusing on a sample of corporations controlled and participated by public authorities, finds that only $20 \%$ of controlled entities and 30\% of participated entities have experienced losses in 2018. As a whole, reported profits are higher than losses, showing how the evaluation of the participation in POEs should be based on other, more complex, features. Actually, a loss-making result can be the effect of an inefficient administration, but also of an inadequate contractual compensation granted for the entrusted public mission. At the same time, profit-making entities can be due to good management, but also to over-compensations and/or granted exclusive market powers. Transparency measures and evaluation criteria should take into consideration this complex framework, providing for a broader concept of performance, where efficiency-oriented indicators need to be merged with more socially-oriented ones.

\section{POEs in Italy: from favour to disfavour}

The deep impulse towards corporatization experienced since the 1990s (Figure 2, above) has been strongly favored by the legislative acts adopted by the Italian government. Initially, Law 142/1990 allowed local governments to manage public

\footnotetext{
12 This evidence is related to local POEs.

${ }^{13}$ The same evidence can be found in Karantounias \& Pinelli (2016), p. 7: "the vast majority of local SOEs are awarded services contracts directly, with no open tender. Lack of compliance with the EU and national legislation on direct award ('in house') is reportedly commonplace".
} 
services through corporations while, later, Law 388/2000 made the transformation of public-law entities (aziende speciali) into stock option companies or limited liability companies compulsory. The use of private law structures has been largely exploited to search for flexibility, specialization and entrepreneurship outside the rigid approach characterizing the public sphere (Karantounias \& Pinelli, 2016; Bertocchi, 2017; Mocetti \& Roma, 2020). The 'escape' argument has been also an opportunity to circumvent constraints on the use of public resources in the post-Maastricht era (Osculati \& Zatti, 2005; Bertocchi, 2017; Corte dei Conti, 2018, 2019; Mocetti \& Roma, 2020).

Three mains criticisms marked this evolutionary trend (Corte dei Conti, 2019). Firstly, distortive effects on competition and proper market functioning have been put in light, due to the limited recourse to open tenders and the privileged position exploited by participated/controlled entities (above all in-house) with respect to other market suppliers. Secondly, inefficient management, operational difficulties and poor service quality have commonly been associated with the wide presence of POEs in the economic sector. Thirdly, opaque financial relations and weaker budget constraints have been sources of misconducts, deviant behaviors and lack of transparency, leading to a widespread negative perception of their role inside the public sphere.

In several cases, both at the State and at the local scale, corporatized POEs have been entrusted also the role of managing indirect participations (through the so-called holding entities) and to carry out functions traditionally developed within the boundaries of the 'core' public administration: development agencies, payment agencies, project management, research and development, consulting, etc. This process is deemed to have weakened the chain of control on shared units, delegating relevant financial and political decisions to a milieu of ambiguity and uncertain accountability (Corte dei Conti, 2018, 2019) ${ }^{14}$.

A progressive change of direction occurred in the first decade of the 21st century. Corporatized POEs, while initially subject to the same laws and regulations as other enterprises, since 2006 have been submitted to specific and increasing limits, special norms and derogations adopted by the Italian legislator ${ }^{15}$. Their reform (downsizing) has been considered an indispensable step also in the spending review of August 2014, where the emphasis has been almost completely directed to the

\footnotetext{
${ }^{14}$ Describing the case of a regional holding, the Court of Auditors underlines how 'the decisional center has been translated outside the public administration, making difficult, from this point of view, the control by the public shareholder... it has been detected that the attribution of a relevant volume of resources to this holding, on the one hand, subtracts them from the direct control of the local public government and, on the other, shifts the decisional barycenter from the political body to the board of directors of the corporation" (Corte dei Conti, 2019, p. 98, own translation).

${ }^{15}$ In the words of Sorrentino (2020, p. 84): 'It brought those unlisted companies in which a public entity held equity back into the bureaucratic administration fold from which they had previously been shooed away'. Only listed SOEs demonstrate no significant deviations from privately held companies (Karantounias \& Pinelli, 2016), being concretely comparable to true market operators.
} 
potential savings obtainable for public finances (Commissario alla spesa, 2014; Karantounias \& Pinelli, 2016; Mocetti \& Roma, 2020). Special rules and restrictive limits have included several aspects (MEF, 2019b): ceilings on the remuneration for the members of the management boards, more stringent recruitment and procurement procedures, controls by the Court of Auditors ${ }^{16}$, detailed boundaries on specific expenditure items (consultancy, advertising, sponsorships, etc.), mandatory adoption of consolidated financial statements covering the entire public administration and the controlled entities, mandatory set-aside of public funds to cover future losses of participated entities.

This evolving process tried to tackle many of the pitfalls and criticisms mentioned before, without a comprehensive vision of the scope and the role of corporatized entities. The multiplicity of provisions introduced, generally focused to relieve single problems (lack of competition, avoidance of public rules, excessive production costs, lack of transparency), contributed to create an instable and uncertain framework (MEF, 2019b), without a resolutive effect on the overall status quo. To overcome this situation, Legislative decree 175/2016 (modified and integrated by Legislative decree 100/2017), the so called 'Consolidated Code of Publicly Owned Enterprises', was approved to integrate and streamline previous fragmented legislation to better manage and rationalize publicly owned enterprises (European Commission, 2016 \& 2019).

The Consolidated Code is based on the 'comply or explain' approach, through which public authorities are required to motivate both the general need of the public intervention, and the more specific choice to rely on a controlled private law entities, with respect to internal production or a regulated externalization. The aim is to reduce the direct public role in sectors not related to the public mission or to the existence of market failures, leaving however to the competent public authority the responsibility to delimit these concepts (MEF, 2019b). It is in fact to be noted that there is not a codification of what is a service of general interest, so that the definitive assessment is left to the autonomous (but nonetheless transparent and accountable) motivation adopted by the public administrations in their periodic review (Belhoncine \& Jirasavetakul, 2020). At the same time, the specific focus on certain quantitative and efficiency criteria (small entities, entities with a negative budget result, high operative costs) concentrates the attention to the possible causes of operational failures in existing POEs, pursuing budget savings and lower public expenditure.

\footnotetext{
${ }^{16}$ The scope of the control of the Court of Auditors is mixed: the Court has always jurisdiction for in house companies; the Court has no power for companies with a minority public share $(<50)$ and for listed companies; for other cases the Court has power only for damages directly caused to the public asset (as in the case of damages to image), but not to the company asset.
} 


Box 1. Consolidated Code of Publicly owned Enterprises ${ }^{17}$ : main contents and provisions
- It applies only to joint stock and limited liability companies.
- POEs must be scrutinized on an annual basis: extraordinary review of their shareholding by September 2017
and annual progress review each year.
- Restrictions and motivations to the use of POEs: established and maintained only if necessary for the pursuit
of the institutional goals of the controlling public authority and/or for providing services of general interest
(comply or explain approach).
- Specific (restrictive) focus on: companies that do not have employees or have more directors than employees;
companies that perform similar activities to those carried out by other publicly-owned companies or by
instrumental public agencies; companies with an average turnover (three years period) less than a certain
threshold18; companies that have been loss-making for four out of the five preceding years; companies that
need to contain operating costs.
- Confirmation of the special rules and restrictive limits adopted for POEs.
- Selection of directors according to principles of honorability, professionality, and autonomy.
- Restrictions and limits are tighter for controlled entities (max. for in-house POEs).

The extraordinary and periodic rationalization plans may bring about two main results: i) the (motivated) intention to preserve the participation without any reform or change or ii) the adoption of different rationalization options (disposal of the holding, change in structure and organisation of the enterprise, merger of the company, liquidation, withdrawal, transfer of shares for free). At present, the process has delivered limited effects, with the retention of $73 \%$ of participations $(76 \%$ in terms of overall employed people) and the adoption of some forms of rationalization for the remaining $27 \%$ (MEF, 2019b). The absence of a clear-cut and more objective definition of the concept of service of general interest, the predominance of a formalistic respect of the law together with the difficulties in identifying and managing adequate disinvestment procedures are considered the main obstacles to a more incisive application of the reformatory framework (Corte dei Conti, 2019; MEF, 2019b; Belhoncine \& Jirasavetakul, 2020).

Finally, the Code does not resolve the intrinsic ambiguity of the use of corporatized public enterprises to pursue the public mission. On the one hand, in fact, their use in this field is subject to several derogations and special norms, so that they represent an in-between option that can complicate the ownership function and the daily management and chain of governance. On the other, they are addressed with methods and criteria often driven (at least formally) by the private sector (profitability, separation of roles, remuneration of directors linked to the financial results ${ }^{19}$, autonomy of the directors, etc.), opening up for potential tradeoffs between financial and non-financial values and objectives.

\footnotetext{
${ }^{17}$ Legislative decree 175/2016 modified and integrated by Legislative decree 100/2017.

${ }^{18}$ Originally set at 1 million $€$ and later reduced to $500.000 €$.

${ }^{19}$ The Consolidated Code specifies that the variable part of the remuneration should be commensurate to the financial results obtained the previous year.
} 


\section{Transparency and Anticorruption policies in POEs}

Italy has recently embarked on a path of wide-ranging structural reforms among which the anticorruption front acquired a key position.

The anticorruption package implemented since 2012 (mainly through Law 190/2012 on corruption prevention in public administrations and Leg. Decree 33/2013 on transparency rules) represented a landmark in the approach adopted, with a policy shift from a (only) punitive approach to a (mainly) preventive one (Box 2). A key role in this direction has been given to the newly established National Anticorruption Authority (ANAC) that soon also assumed a surveillance and supervision role on public works. Broad anti-corruption plans have been launched since then to both consolidate the initiatives already launched (efficiency of public administration, transparency and public access to information, increased citizens' participation in public decision-making, etc.) and develop new ones (prevention of conflicts of interest, rotation of personnel, adoption of code of ethics, whistle-blower protection, etc.).

\section{Box 2. Main anticorruption and transparency measures introduced by L. 190/2012 and Leg. Decree 33/2013 for all public entities}

- Identification, within the organisation, of a person Responsible for Corruption Prevention and Transparency (RCPT) who must assess the suitability of the corruption prevention and transparency plan and oversee both its implementation and operation and the effectiveness of the control procedures and processes.

- The RCPT is appointed by the political board among the organization's executives. The RCPT must be assigned functions, powers and resources adequate for carrying out his/her role with full autonomy and effectiveness.

- Formal adoption of a Three-Years Plan for Anti-corruption and Transparency that identifies and assesses the main activities and areas at risk of corruption (procurement, staff recruitment, grants and donations policies, tariff definition, appointment and nomination rules and control and inspections).

- Adoption of specific risk prevention measures, which coincide with procedures and protocols that cover sensitive issues such as: conflict of interest, authorization to make appointments outside the company, incompatibilities and ineligibility for top positions, whistleblowing, the rotation of staff and training.

- Adoption of a code of ethics and conduct: a set of values, principles, and guidelines for behavior to which employees should aspire for as part of their belonging to a public organization.

- Full integration of transparency measures into the corruption prevention model.

- Creation of a specific section of the internet site, named 'Transparent Administration', dedicated to the publication of information regarding the organization and its activities.

- Full civic access by citizens to data, documents and information held by the organization and not published on the section 'Transparent Administration'.

In this evolving framework, POEs have been handled in line with their ambiguous nature, privileging initially their private dress and, later one, shifting to the public one.

Since 2001, POEs have been required to apply the Legislative Decree no. 231 issued to implement the OECD Convention of 17 September 1997 on the fight against corruption. The Decree covers a large range of offences (including active corruption) that can be committed by persons in the interest or to the advantage of the company, providing a new form of liability for all private-shaped companies, which the legislator 
describes as "administrative", independent from the liability of the executor who has actually committed the crime (Previtali et al., 2018). In fact, under articles 6 and 7 of the Decree, in a case of corruption or bribery the company body may be exempted from liability if it can prove it has adopted and effectively implemented some organizational and governance measures (Model 231) such as the following (Previtali, 2017):

(a) the Board of Directors adopted and efficiently enacted, prior to commission of the act, organizational and management models which can prevent offences of the type occurring;

(b) the task of overseeing such operations has been delegated to a Supervisory board vested with powers to act on its own initiative and conduct monitoring;

(c) the persons committed the offence by fraudulently circumventing the organizational and management models;

(d) there has been no omission or insufficient oversight on the part of the Supervisory board referred to in subparagraph (b).

In the last decade the viewpoint changed radically due to the emergence of a different vision of POEs. If we concentrate on corruption prevention, in fact, the perspective to be adopted for a POE should be designed in accordance with its mission and operating environment. In fact, the director and managers can be, as in a private entity, active agents in corruptive behaviors, trying to gain contracts and benefits for the enterprise (Belloc, 2014); but they can also be passive subjects when they demand money, gifts or other undue advantages to act or to refrain to act in the exercise of their function, thus penalizing the interests of the company and, as a consequence, of the general public (Dela Rama, 2011; Previtali et al., 2018; Ye \& Hu, 2019).

As we have observed above, most POEs in Italy are controlled by public shareholders ( $60 \%$ of total POEs, representing $75 \%$ of employed people) with limited or no financial relation with third parties outside the public sphere, if we exclude the revenues obtained by user tariffs and service charges (Corte dei Conti, 2019). This figure is emphasized in the in-house case, where financial and commercial relations with private entities are the facto excluded. In all these instances the space/risk of bribery and active corruptive actions is limited, making the relevance of Leg. Decree n.231/2001 almost ancillary. When a public enterprise is entrusted with important public policy objectives and do not operate under a commercial logic, passive bribery is clearly predominant, being a concrete threat for the general interest pursued. Many operative areas can be involved: administrative acts and authorization, contracts awarding procedures, grants and other donations policy, workforce recruitment and career progression, tariff definition, appointment and nomination rules, control and inspections. In this perspective, passive and active corruption, certainly related and equally deplorable from an ethical point of view, are to be kept distinct so 
as commonly separated/complementary are policies aiming to their prevention and control.

For these reasons, following the adoption of the Law 190/2012, an increasing relevance has been directed to POEs as a source of passive corruption behaviours. At the same time, considering their wide presence at the national and local levels, improving anti-corruption and transparency in their conduct became a key option to improve the overall effectiveness of the public sector. As a result, after two years of uncertainty, ANAC, recognizing the special character of these entities, approved in 2015 (Deliberation 8/2015) specific guidelines on the application of the anticorruption and transparency discipline within POEs. These Guidelines have been integrated and updated in 2017 through the Deliberation ANAC n. 1134/2017.

The general approach is based on the same principles defined for public administrations, but with some adaptations to the specific context of private law entities (Bertocchi, 2017). It also established a different level of applicability depending on the share of public participation in the company. The discriminatory criteria used by the ANAC guidelines to define the applicability for POEs of the rules adopted for public administrations is the existence of public control ${ }^{20}$ and the managing by the enterprise of activities of public interest (ibidem).

Enterprises under public control are required to implement anti-corruption and transparency measures at the same way as public administrations. These companies are de facto completely assimilated to public administrations, with the need of introducing all the organizational and operational instruments provided by Law 190/2012 and Leg. Decree 33/2013. On the one hand, they must design risk assessment (Box 3 ) and risk prevention measures, coinciding with procedures and protocols that cover sensitive issues, with a specific focus on passive corruption. These sections can be included within a specific 'Three-Years Plan for Anti-corruption and Transparency' or as a special part of the Model 231 previously adopted according to their private-law formal shape. On the other hand, they are required to reinforce and standardize transparency and disclosure measures, to be fully integrated in the general anti-corruption plan.

\footnotetext{
${ }^{20}$ As stated by Legislative decree $175 / 2016$, public control exists when: i) public shareholders have the majority of votes in the shareholders' meeting; ii) public shareholders have sufficient voting rights to exercise a dominant influence in the ordinary shareholders meeting; iii) a company - regardless of the direct participation by the public administration - is under the dominant influence of the public by virtue of particular contractual links; iv) the control of a company is exercised jointly by a plurality of administrations through specific pacts, statutory norms or agreements.
} 


\[ \text { Box 3. Main risk assessment factors (Probability x Impact) } \]
- Level of directionality
- External relevance of adopted decisions
- Economic relevance of operations and their consequences
- Frequency of operations
- Previous corruptive events and misuse regarding the same operation/factor
- Reputational impact

Source: our elaborations on ANAC, 2018.

Companies under public participation are characterized by a vaguer implementation of the anti-corruption and transparence package. They are not required to formally nominate an RCPT (Responsible for Corruption Prevention and Transparency), nor to implement the discipline on corruption prevention established by Law 190/2012. At the same time, public authorities should encourage their participated entities to implement the 'Model 231', integrating also organizational and executive measures to prevent passive forms of corruption and mismanagement. The adoption of transparency and publication requirements (ex Leg. Decree 33/2013) are mandatory only for data and documents related to activities of 'public interest governed by national or European Union law'21. The same perimeter applies for civic access. To accomplish these requests, participated companies should deliver, within their organization, a monitoring and certification activity regarding disclosure requirements. This function is preferably entrusted to the Supervisory Board under Leg. Decree 231/2001, without prejudice to the internal organizational choices considered most appropriate, given the need to limit operative costs and to rely on the already existing control systems.

Finally, as far as listed companies are concerned, both in the case of control or simple participation, they are subject to the same regime as participated entities: encouragement to implement the 'Model 231' and adoption of transparency and publication obligations concerning activities of 'public interest'. Moreover, the general provisions included in the Consolidated Code of Publicly Owned Enterprises do not apply, as it is supposed that the market discipline they are exposed to is a mechanism suitable to guarantee enough accountability and transparency. On this point, as underlined by the Court of Auditors (Corte dei Conti, 2019), their ambiguous nature emerges once more. In fact, while market pressure and control can be adequate to monitor their financial and economic situation, these are not necessarily a correct way to pursue other, more general, interests entrusted to the shared company. At the same time,

\footnotetext{
${ }^{21}$ Public interest activities include the exercise of administrative functions, the provision of goods and services for the public administrations and the provision of public services (services of general interest). In the absence of a clear-cut delimitation of the concept of public interest, the POE and, even more, the public entity owning the POE, is expected to exactly single out what can be considered of public interest in order to guarantee an adequate regime of corruption prevention and transparency.
} 
if disclosure obligations should not compromise essential corporate confidentiality and should not penalize POEs with respect to private competitors, such obligations represent as well a key instrument to disclose the fulfillment of social and noncommercial objectives. Again, ambiguities and grey area effects may arise.

ANAC enforced a double compliance regime for POEs: public enterprises are invited to comply with Legislative Decree no. 231 as private companies, but, at the same time, they are obliged, at different degrees, to comply with Law no. 190 (Previtali, 2017). With reference to in-house cases, ANAC fully equates POEs to public administrations. From here, the risk is to create redundancies and unclear boundaries between the two systems: the organizational model and the supervisory body established under Decree no. 231 risk overlapping with the adoption of the corruption prevention plan and the appointment of a compliance officer, as explicitly stated by the Law no. 190. The risk here is the creation of an "over-compliance framework" which can lead to a "conformity trap" (Vit, 2016). Moreover, this complex regulatory framework could apply a "rule-based compliance", creating the conditions for a "protect and justify" approach to possible failures of POEs (as well as the behavior of poorly performing employees).

\section{Some concluding remarks on the Italian experience}

POEs, and particularly corporatized public enterprises, turned out to be a distinguishing feature of the Italian public intervention in the economic system in the last three decades. Among the different and controversial consequences brought about by their diffusion, an increasing interest has been directed to the effects on the overall accountability and integrity of the public sphere.

POEs, in fact, may "benefit" from less rigid decision and control mechanisms that could potentially be used for committing corrupt and fraudulent crimes. As a consequence, the process of escaping from the rigid and bureaucratic legal framework of public administration into the relative freedom of the business sector can bring about a perverse result: that of creating freedom and lessening control coupled with more opaque systems of political rewards and penalties.

The anticorruption package adopted in Italy in the last decade has promoted important steps to prevent this menace. It is in fact based on a systematic approach to risk management, providing that the mechanisms for risk prevention and control are closely interconnected with performance appraisal, transparency and general accountability. Yet, the effects of these new measures have not been resolutive, and many challenges are still open.

Multiple and contradictory rationales and governing rules have led to an inadequate conduct of POEs, largely stigmatized by the national Supreme audit institution. Corruption and mismanagement events frequently involved POEs, shedding light on their weak organizational and accountability systems. At the same time, the mere 
introduction of anti-corruption and transparency rules turned out to be not sufficient to create the conditions to implement innovative practices and policies in POEs. The anticorruption and compliance mechanisms characterized just by rule-based processes may have negative consequences especially in POEs, reducing these mechanisms to an add-on for internal control and compliance to external regulations, derailing any real process of hybridization with the pre-existing management systems and practices.

In this perspective, the main challenge seems to be that of promoting a better set up of POEs' internal organisational models, consistent with the mission there are entrusted. The case of corporatization we have described is in many cases coherent with the provision of services and functions where the control and influence exerted by the public owner should be kept high to safeguard the public mission. Often corporatized enterprises derive from the transformation of public agencies, so that they do not operate in a competitive environment and are strictly linked to the territory and the political structure they originate from. These features are emphasized in the case of the so-called in-house option, where there is not a true delegation to a third party and the concept of internal regulation still applies. In these circumstances many of the recommendations usually adopted for POEs can be misleading or hardly applicable. That is true, for example, for concepts like stock markets listing or competitive pressure, but even as far as de-integration and depoliticization of the board of director are concerned. While, in fact, the idea of relying on directors and bureaucrats with higher technical and business experiences, selected through transparent and well-designed criteria, is certainly to be welcomed, it must also be ensured that political or policy goals are still central in the company strategy and actions to avoid that it loses its focus on public interest and thus becomes politically questionable. In these cases, the public authority/organising authority must act as an informed and active owner, defining the overall rationale for state ownership, establishing statutes and procedures for effective steering and control and ensuring that the link with the controlled entity is carried out in a transparent manner. Diversely, when POEs are more market oriented and operate in a competitive environment, the private-like approach can prevail, contributing to a level playing field with other operators.

Also anti-corruption devices must be designed in a similar manner. Where the public mission is prevalent, the public-oriented approach should lead, with public governments responsible to put in practice a unitary system of steering and control of their owned entities. Until know, as stated by the Italian Court of Auditors (Corte dei Conti, 2019), there has been an 'insufficient awareness of this steering role' (p. 180), leading to the recommendation to develop for the future (p. 35): 'a strong governance on participated entities, to guarantee the continuous monitoring of their results and of their effects on the financial equilibria of the controlling governments'. In this perspective, POEs must be subject to particular pressures given the strong interaction of business considerations with political and public policy ones. 
Laws, regulation and codes have a role in this direction, but cannot be enough and can also be too much in some cases, leading to over-compliance and conformity trap effects. Separation of commercial and non-commercial objectives, clear focus on the public policy assignments, higher burden of responsibility, ethics programme that emphasize values, self-governance, identity, training, trust and demanding stakeholders could be important integrative elements of the future agenda in this field.

\section{References}

Alexius S., Cisneros Ornberg J.C., 2015, 'Mission(s) impossible? Configuring values in the governance of state-owned enterprises', J. Pub. Sector Manage. 28(4/5):286-306.

ANAC, 2018, Relazione 2018, Roma.

Belhoncine N., Jirasavetakul L., 2020, Lessons from Two Public Sector Reforms in Italy, IMF Working Paper, WP/20/40.

Belloc F., 2014, 'Innovation in State-Owned Enterprises: Reconsidering the Conventional Wisdom', J. Econ. Issues 8(3):821-848.

Bertocchi M., 2017, 'Transparency in Local State-Owned Enterprises in Italy', Symphonya. Emerging Issues in Management, 2, 31-46.

Commissario alla spesa, 2014, Programma di razionalizzazione delle partecipate locali.

Corte dei Conti, 2018, Gli organismi partecipati dagli enti territoriali. Relazione 2018, Deliberazione N.23/SEZAUT/2018/FRG, Roma.

Corte dei Conti, 2019, Gli organismi partecipati dagli enti territoriali e sanitari. Relazione 2019, Deliberazione N.29/SEZAUT/2019/FRG, Roma.

Curci N., Depalo D., Vadalà E., 2017, Municipal socialism or municipal capitalism? The performance of local public enterprises in Italy, Banca d'Italia, Questioni di Economia e Finanza, number 408.

Dela Rama M., 2011, 'Corporate Governance and Corruption: Ethical Dilemmas of Asian Business Group', J. Bus. Ethics 109(4), 501-519.

European Commission, 2016, State Owned Enterprises in the EU: lessons learnt and ways forward in a Post-Crisis Context, European Economy, Institutional paper 031/ July.

European commission, 2019, Country Report Italy 2019 Including an In-Depth Review on the prevention and correction of macroeconomic imbalance, SWD(2019) 1011 final.

Grossi G., Reichard C., 2008, 'Municipal Corporatization in Germany and Italy', Pub. Manage. Rev. 10(5), 597-617.

ISTAT, 2020, Le participate pubbliche in Italia. Anno 2017, Statistiche Report, Febbraio.

Karantounias V., Pinelli D., 2016, Local State-Owned Enterprises in Italy: inefficiencies and ways forward, European Economy, Economic Brief 010, April.

McDonald D.A., 2016, 'To corporatize or not to corporatize (and if so, how)', Utilities Policy 40:107-114. doi.org/10.1016/i.jup.2016.01.002 
MEF, 2019a, Rapporto sulle partecipazioni delle Amministrazioni pubbliche. Dati 2016. Dipartimento del Tesoro, Roma.

MEF, 2019b, Rapporto sugli esiti della revisione straordinaria delle partecipazioni pubbliche, Roma.

Mocetti S., Roma G., 2020, Da 8.000 a 1.000? Razionalizzazione e governance delle società pubbliche, Banca d'Italia, Questioni di economia e finanza, Occasional papers, n. 570.

Osculati F., Zatti A., 2005, 'The Services of General Economic Interest. The Case of Local Public Transport in Italy', /l Politico, n.3, pp. 411-447.

Previtali P., 2017, 'The application of legislative decree no. 231/2001 through organizational models: rethoric or real effectiveness?', Impresa Progetto - Electronic Journal of management, n.2, 2017.

Previtali P., Zatti A., Scarozza D., 2018, 'Public owned enterprises in Italy: A hybrid nature for a hybrid regime of over-compliance', African Journal of Business Management, 12(6), pp. 140-153.

Vit G., 2016, Over-Compliance and the Conformity Trap. Paper presented at European Group for Organization Studies Conference, Naples, Italy.

Wollmann H., 2018, 'Public and Personal Social Services in European Countries from Public/Municipal to Private-and Back to Municipal and "Third Sector" Provision', International Public Management Journal, 21:3, 413-431.

Ye S., Hu S., 2019, Research on Mixed Ownership Reform, Executive Corruption and Corporate Performance, 2019 International Seminar on Education, Teaching, Business and Management (ISETBM 2019).

Zatti A., 2013, European Local Public Transport between Convergence and Diversity, in Paramithiotti G. (eds.), 'Servizi pubblici e imprese pubbliche in Europa tra convergenza e sussidiarietà', Quaderni della Rivista il Politico, 60, 123-158.

Andrea Zatti is Researcher of Public finance in the University of Pavia, Italy, and Professor of European public finance and Local public finance at the Faculty of Political Science, University of Pavia.

He also chairs the Romagnosi Foundation - Local Government School and he is Rector of the Cairoli College, Pavia.

Andrea Zatti has worked in the research area with ISPRA (Italian National Environmental Agency), CIRIEC (International Centre of Research and Information on the Public, Social and Cooperative Economy) and OCSE on public finance themes and environmental and territorial issues. 


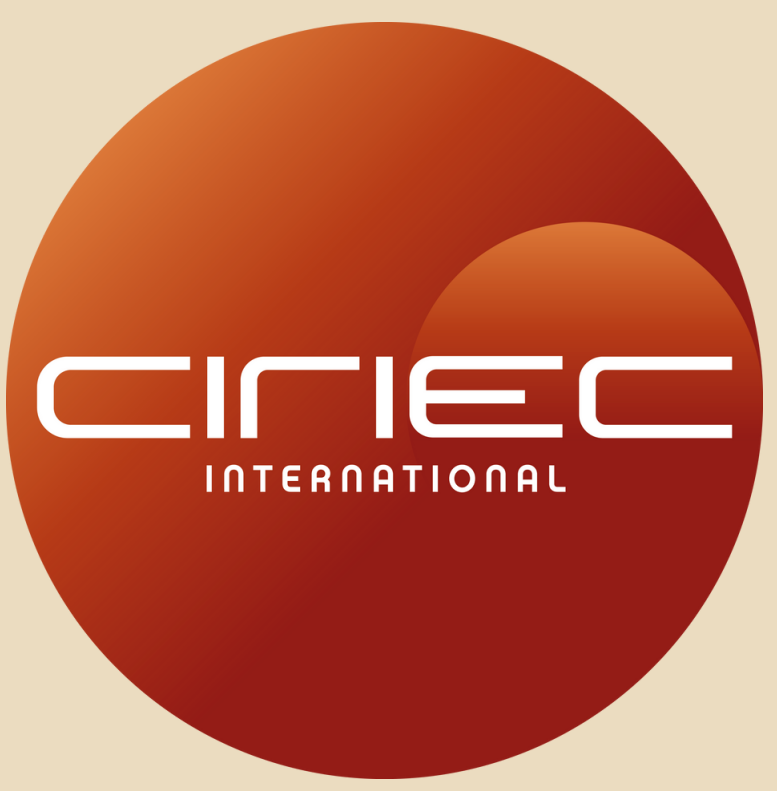

The CIRIEC STUDIES SERIES proposes research results from working groups and commissions of the CIRIEC scientific network in both social and cooperative economy and public economy.

To facilitate accessibility to those research works, this electronic series is proposed in open access, on CIRIEC's website, but also as new series in RePEC.

Each study is available and downloadable as a whole document but also chapter by chapter.

\section{$\triangle$ ciriec@uliege.be} www.ciriec.uliege.be 